\title{
Asset management of transportation companies: Analysis and methods
}

\author{
Michael V. Zharikov ${ }^{1, *}$, and Irina I. Shatskaya ${ }^{2}$ \\ ${ }^{1}$ Financial University under the Government of the Russian Federation, Russia \\ ${ }^{2}$ Russian University of Transport, Russia
}

\begin{abstract}
The article deals with gaining some ideas and skills that an investor might use to choose the best opportunities in the market from among the thousands of options concentrated in the transport industry. The authors are also trying to build up a standard set of tools that make up the core of every stock analyst's tool box. From the practical perspective, the ideas and techniques in the discussion part will be useful for analysing just every possible investment. A special focus in the article has been made on the transportation companies struggling with the consequences of the corona-crisis of 2020.
\end{abstract}

\section{Introduction}

Although investors tend to associate financial statement analysis with picking stocks, it is actually just as important for bond investors. It does not really matter who is issuing the securities either. Sovereign debt investors do financial statement analysis on governments, and retail lenders do financial statement analysis on households. However, the major stress here will be made on companies from the transport sector of the economy. Financial statement analysis, among other things, is the practice of forming ratios and other statistics using the numbers presented in a set of financial statements, i.e. the firm's financial accounts. The idea is that although the numbers in a borrower's financial statements already tell us a lot of good information, we can learn even more about a borrower's financial condition and performance if we combine or compare these numbers in creative ways. This information will hopefully give us a clearer picture of which transportation firms are more attractive investment opportunities [5].

In order to find the best investment opportunities in the transport industry, we will have to first make a little bit of reminder on accounting, at least some introductory definitions that are used all the time in practice. In later parts, we will also need to take a brief look at the overall structure of a particular transportation company's financial statements and learn what information is presented where [3]. Once we have done that, we will construct some of the most important ratios and other statistics, and explain what all these numbers are trying to tell us about the condition or performance of the transport company. As we get into knowing about the ratios themselves, we will also explain how to use these numbers when selecting stocks or bonds of the transportation companies. When selecting investments, however, this

\footnotetext{
${ }^{*}$ Corresponding author: michaelzharikoff@gmail.com
} 
information is also useful for gaining a better understanding of a transportation company's financial condition and performance which these days of the corona-crisis is not a bad thing to know. In addition, it is of practical importance to put together a set of financial statements for a transportation or infrastructure venture as well as projected values of certain financial ratios into the future for the time when the world will have passed the days of lockdowns and quarantines [12]. The obvious place to start understanding the workings of financial statement analysis is a transportation company's financial statements.

\section{Materials and Methods}

The financial statements try to show a concise, sometimes even a complete picture of a transportation company's finances. They consist of four main parts: three different tables that correspond to the main financial activities of the transportation firm plus a set of notes that explains a lot of the details that omit it from the three different tables for the sake of brevity [9]. The three tables or statements are the income statement, the statement of cash flows and the balance sheet. We are now going to go through these tables or statements and discuss what they tell investors [13].

We will start with a financial statement containing the information that stock investors seem to pay the most attention to - the income statement. If you stop and think about what you would most like to know about the financial condition of a transportation company, it is probably whether the company is making any money. The income statement, also called the statement of earnings or the statement of operations, presents a detailed answer to that question. It gives an overview of how much revenue the transportation company brings in, how much it pays out as various expenses and then how much profit is left over if any [1].

Since it is much easier to understand financial statements and financial statement analysis with an example in front of you, we are going to introduce that now. We are going to work with the financial statements of the C.H. Robinson. We pick this transportation company, mainly because we have noticed that they always present a very simple and clean set of financial statements. So, they are great for people trying to understand the workings of the financial statement analysis. Besides, its service is one of the best in the industry.

C.H. Robinson has diversified its line of services well beyond simple delivery. There are plenty of other services and prepared items to think about as well. Suppose the first question is where do we get the statement. Go right to the source - the company website and look for links to company information or investor relations. Eventually, we find our way to the latest annual report. The annual financial statements are always in the annual report. Publically traded companies are required to report their financial results quarterly. We can get more upto-date information by viewing the quarterly financial statements. Most companies these days do link to these on their websites as well. But the US Securities and Exchange Commission (SEC) also has these data as part of their so called Edgar Database, and many financial websites including free ones also post financial statements from publically traded companies [11]. The only complaint about the financial websites is that they take the company's actual financial statements and then move the information into a one-size-fits-all financial statement template. After you get some experience looking at different companies' statements, you will realise that there is actually a lot of variation in how the information gets reported. Unfortunately, when these financial websites translate the financial statements into their templates, sometimes good information is lost in translation.

So, let us have a look at C.H. Robinson's income statement which they call a consolidated statement of earnings. Earnings is the finance word for profit, and as we will see the income statement shows fairly clearly how C.H. Robinson calculate their profits. The top of the income statement is net sales which is sales minus returns. Other companies will just have a 
number for sales or even revenues. C.H. Robinson sold nearly 16.2 billion dollars' worth of services in the pandemic year of 2020.

Then below the sales come all the expenses of running the company including production costs, marketing costs, R\&D and administrative expenses [10]. After we subtract those expenses, we have a rough statement of earnings which goes by two names. One name is operating income and the other is EBIT, which is an acronym that stands for earnings before interest and taxes. For C.H. Robinson this turned out to be about 628.3 million dollars. You may have also heard the EBIT's cousin - EBITDA which stands for earnings before interest, taxes, depreciation and amortisation. You will notice that you do not see depreciation and amortisation listed on the income statement, and you will have to find it somewhere else. If we take EBIT and subtract off interest, and then income taxes what we call them corporate income taxes but they are actually taxes on corporate profits, then we get to net income or net earnings. This is so called the bottom line on the income statement. For C.H. Robinson this number was 506.4 million dollars in 2020. Net income tells the stock investor all the profits that could be paid out to the shareholders. You may recall, though, that most firms do not pay out all these earnings as dividends, especially in the pandemics year of 2020.

The last thing that an income statement typically does is that it calculates the earnings per share or EPS of the firm. This is done as a convenience, since so many investors want to see the profits on a per share basis. Otherwise investors would have to dig up the information on a number of shares that the firm has outstanding. C.H. Robinson earned 3 dollars 74 cents per share in 2020 .

It is tempting to think that as a C.H. Robinson's shareholder you have acclaimed 3 dollars and 74 cents in cash for each share you hold. But you actually do not. The income statement tells you what the accounting measures of profit are, but the truth is that accounting measures of profit are not equal to cash. This is because most accounting is done under the principle of accrual.

Accrual refers to one particular set of procedures for recognising revenue and expenses. Business transactions get pretty complicated, and we need a set of simple rules for making sense of these transactions. Accrual is the most popular way to do this [2]. But one of the costs of its flexibility and simplicity is that accrual-based measures of income and expenses are not equal to the actual cash payments going into and coming out of the transportation firm. For example, suppose C.H. Robinson makes a deal to sell a million dollars of transportation services over the next three years to a company that operates a home office on its outlets. Talk about a seller business. Under the principle of accrual C.H. Robinson can record the entire one million dollars in sales now as soon as it has the signed sales agreement. The accounts at C.H. Robinson do not have to recognise the revenues immediately, but they can if they want to. The sales numbers do not necessarily tell you about the money flowing into and out of the transportation company. Needless to say, investors are really interested in knowing how much cash is being generated by the transportation company. Veteran business owners and anyone who has ever started the transportation business know that companies generally go out of business because they run out of cash, not because they do not necessarily make accounting profits. Fortunately, there is another financial statement that addresses the need to know about cash. It is called the statement of cash flows [6].

\section{Results and Discussion}

The purpose of this section is to simply give investors a clearer picture of how much cash the transportation company is taking in, and how it is using cash. Investors use the statement of cash flows primarily to see whether the transportation company is bringing in more cash than it is spending. Happiness is positive cash flow. First, note that on the statement of cash flows the transportation company's use of cash is broken down among operations, investing and 
financing. One thing that is always worth checking is to see whether the transportation company's operations, the things that it is actually in business to do, are bringing in more cash than they use. For C.H. Robinson this cash flow from operations were net cash provided by operating activities of just over a billion dollars. Also, at the bottom of the statement we can see whether the company as a whole increased or decreased its holdings of cash. Some investors use the statement of cash flows quite intensively, but nearly all investors find two pieces of financial information particularly useful.

The first piece of information is the depreciation and amortisation expense which is counted as a production expense on the income statement. Depreciation and amortisation attempt to keep every company honest about the fact that its factories and equipment are wearing out and will have to be replaced some time. Using up these real assets is a real economic cost but not one it causes any money to change hands. If a transportation company reports a depreciation expense, its earnings fall but its cash is not actually affected [8].

The second item on the statement of cash flows that most investors like to know is called free cash flow. This does not directly appear on the statement of cash flows but it can be calculated directly and easily from it. Free cash flow measures how much cash the firm could be returning to shareholders. It is the cash flow analogue to net earnings on the income statement. Analysts like to calculate free cash flow in different ways but nearly everyone starts with cash flow from operations and then subtracts off capital expenditures, which is usually the first item in the section on cash flows from investing activities. Capital expenditures are purchases of real assets like equipment and factories. Given how most financial statements are laid out, cash flow from operations and capital expenditures are almost always next to or at least close to each other. For C.H. Robinson we know that cash flow from operations is 1.057 billion. And just below it is an item for purchases of plant assets, which is 315 million dollars. The numbers in parenthesis do indicate that it is an expense. So, our basic measure of free cash flow for C.H. Robinson is 1.057 minus 315 or 742 million dollars.

Notice that for C.H. Robinson there is a fairly close correspondence between the accounting measure of profit - net earnings - and the cash measure of profit - free cash flow. But again, given the differences between accounting principles in cash flow, this is not necessarily the case for any given company. Many investors will do all the same things to free cash flow that they do with earnings. Especially, though they are divided up by the number of the shares in the firm to get the free cash flow per share. The income and cash flows of the firm are important, but if we stop there, we leave out an essential part of the firm's financial story [4].

Transportation firms issue financial assets in order to borrow money from investors, so they can buy real assets - rail roads, trucks, ships, etc. The financial statement that lasts - the balance sheet - tells part of the story. A balance sheet is a snap shot of the transportation company's assets, liabilities and equity at a point in time. We use the term assets for anything the firm owns and liabilities for what the firm owes to other parties. Equity or net worth is the difference between assets and liabilities. It tells you in accounting terms what the entire company is worth. On C.H. Robinson's balance sheet it had about 3.3 billion dollars in assets and just over 1.8 billion dollars in liabilities as of March 2020. That implies that C.H. Robinson's equity was 2.2 billion dollars.

Many investors also refer to balance sheet equity as book equity where the book in question is the company's accounting books. The term book value of the company makes clear that we are talking about the accounting value of the firm's equity from the balance sheet rather than the market value of the company [7].

We have seen the financial statements and learned about the basic information they contain. The financial statements already contain a lot of information about a firm's performance, numbers such as EBIT, free cash flow, net earnings and net worth, all tell 
essential information that helps us understand the company. But there is a lot more we can do with these numbers. In fact, there are entire university courses and entire books on financial statement analysis. Our goal is to give what is considered to be the most important financial ratios that nearly all investors know and use to help them pick stocks. Each ratio represents an entire category of ratios that are designed to measure some crucial aspect of a company's financial performance.

The first category of financial ratios are called liquidity ratios. Liquidity ratios measure whether a company has enough money to pay all the bills coming due. A standard liquidity ratio is the current ratio which is defined as current assets over current liabilities (Formula $1)$.

$$
C_{\text {ratio }}=\frac{C_{\text {assets }}}{C_{\text {liabilities }}}
$$

The word current here is an accounting term that means that it comes due within the next twelve months. The current ratio says how many dollars of current assets the transportation company has for each dollar of current liabilities, or in other words, how many dollars the company thinks it will receive in payments over the next year divided up by the number of dollars of bills it thinks it will have to pay during the next year. C.H. Robinson has current assets of 1,687 million and current liabilities of 2,065 million. These numbers give a current ratio of about 81.07 . This means that C.H. Robinson currently has about 87 cents in shortterm assets for each dollar of liabilities that it expects to have to pay during the current year. These short-term assets should be converted to cash within the next twelve months. For transportation firms like C.H. Robinson the current ratio can be a bit misleading because inventories make up a lot of the firm's current assets. For example, C.H. Robinson has 724 million dollars in inventories which is almost half of its current assets. But it may be hard to liquidate inventories in a hurry, and if the company is forced to do that, it may have to sell the inventories of trucks and ships at very low prices.

For many transportation companies analysts also calculate a related liquidity ratio called the quick ratio. The quick ratio still puts current liabilities in the denominator, but the numerator only contains cash, securities and accounts receivable (Formula 2).

$$
Q_{\text {ratio }}=\frac{(\text { cash,securities,accts receivable })}{C_{\text {liabilities }}}
$$

Accounts receivable, by the way, is the amount of money that C.H. Robinson's customers owe it for the services that they have purchased. For C.H. Robinson we calculate the quick ratio this way: cash and investments are 254 million dollars and accounts receivable are 512 million for total of 766 million dollars. Then we divide 766 million by the total current liabilities of 2,065 million. And this gives us a quick ratio of 0.371 or 37.1 cents in cash, securities and accounts receivable for every dollar in current liabilities. What do these financial ratios mean? Taken by themselves, we do not really know whether these ratios are good, bad or indifferent. That is because these ratios have very little meaning by themselves. They are really to be used by comparison with other firms' ratios.

The next set of ratios are leverage ratios. Leverage measures how much the firm is borrowing. Leverage is a two-edge sword. A bit leverage can do you good, but too much leverage is just plain dangerous. That goes for companies as well as individual investors. There are lots of ways to measure leverage. Although some investors like to use debt-toequity ratios, we tend to prefer leverage ratios expressed as total assets over total equity (Formula 3).

$$
L_{\text {ratio }}=\frac{T_{\text {assets }}}{T_{\text {equity }}}
$$


C.H. Robinson's total assets are 6,276 million, and their equity is 929 million. That means that total assets over total equity is equal to 6,276 divided by 929 or 6.76 . This means that every dollar of equity supports 6 dollars and 76 cents of assets. This view gives you a very clear idea of the extent of the leverage and what it is being used for. You can still take this number and deduce that for every dollar of equity that the shareholders have contributed along the lines, the managers have borrowed another 5 dollars and 76 cents. The next category of ratios is the profitability ratios. One of the profitability ratios that most investors look at is the operating margin which is defined as EBIT divided by sales (Formula 4).

$$
O_{\text {margin }}=\frac{E B I T}{\text { sales }}
$$

EBIT is also called operating income which is the connection to operating margin. This ratio simply tells us what fraction of each dollar of sales goes to operating income. It is clear that this is the profit margin. C.H. Robinson's EBIT is 673.3 million. Its sales are 16,207.1 million. So, the operating margin is 673.3 divided by $16,207.1$ gives 0.041 . That means that 4.1 cents of every dollar of sales is operating profit.

Now we will move on to efficiency ratios. Efficiency describes how well a company utilizes its assets. One of the main efficiency ratios is called the asset turnover ratio, which is defined as sales divided by total assets. Note that many financial analysts use average total assets and the denominator of that ratio (Formula 5).

$$
A T_{\text {ratio }}=\frac{\text { Sales }}{T_{\text {assets }}}
$$

C.H. Robinson's sales were 16,207.1 million, and the total assets which we saw in the leverage calculation were 5,144.3 million. This makes the asset turnover ratio equal to $16,207.1$ divided by $5,144.3$ or 3.15 . This is literary saying that every dollar of C.H. Robinson's assets produces 3 dollars 15 cents of sales per year.

Finally, the best financial ratios that every investor wants to know right after bet are ROA and ROE which are return on assets and return on equity. These are so called performance ratios. They try to measure in an accounting sense the return that different investors would get by lending a dollar to the company. First, let us start with ROA. This is defined as EBIT minus taxes, their quantity divided by total assets. The numerator measures the profits that are available to be distributed to both the bond holders and to the stock holders of the company (Formula 6).

$$
R O A=\frac{E B I T-\text { taxes }}{T_{\text {assets }}}
$$

In fact, ROA calculates the return you would earn again measured in accounting terms and not market terms if you finance a dollar's worth of the company's assets by buying both the company's corporate bonds and its stock. ROA assumes, moreover, that you finance the company by buying its stock and bond in the same proportions as the company has listed on its balance sheet. So, for C.H. Robinson you are buying about five dollars and 76 cents worth of bonds for every dollar you buy of stock. EBIT once again was 628.3 million. Taxes paid were 398 million. This makes the numerator equal to 230 million. Then total assets once again $5,144.3$ million. So, the ROA ratio is 230 divided by 5,144.3, which gives 0.045 or $4.5 \%$. Finally, let us do ROE. ROE is defined as net income over equity (Formula 7).

$$
R O E=\frac{N_{\text {income }}}{\text { equity }}
$$

C.H. Robinson's net income was 844 million. And its equity was 929 million. This makes the ROE ratio 844 divided by 929 , which gives 0.909 or $90.9 \%$. That seems really high. Is it 
realistic? To answer that, we really need to compare C.H. Robinson's ROE to the ROEs from a similar set of companies such as Brambles or Orient Overseas. C.H. Robinson's financial ratios have very little meaning by themselves. They are really meant to be compared with other firms' ratios. In order to use financial statement analysis to help you pick stocks, you will have to select a set of similar firms and then compare ratios. If one firm's ratios are impressive relative to its peers, then it is probably worth doing further analysis on it to see whether it is worth adding to your portfolio. Let us do this comparison on ROE for C.H. Robinson. If you go to about any financial website and look up C.H. Robinson, the site will probably list that C.H. Robinson is in a transportation sector. What we can do is look up several firms from this industry that seem likely they would be similar to C.H. Robinson and compare their ratios to C.H. Robinson's. One way to choose similar firms is to find a list of companies in the industry sorted by market capitalisation. According to companiesmarketcap.com, the top performing transportation companies globally by market capitalization are shown in Table 1.

Table 1. World's top 10 transportation companies by market capitalization, 2021.

\begin{tabular}{|l|l|l|l|l|l|}
\hline Rank & Company Name & $\begin{array}{l}\text { Market cap, } \\
\text { bln \$US }\end{array}$ & $\begin{array}{l}\text { Share price, } \\
\text { \$US }\end{array}$ & $\begin{array}{l}\text { Average daily } \\
\text { change, \% }\end{array}$ & $\begin{array}{l}\text { Country of } \\
\text { origin }\end{array}$ \\
\hline 1 & $\begin{array}{l}\text { United Parcel } \\
\text { Service }\end{array}$ & 150.42 & 173.02 & 0.62 & USA \\
\hline 2 & FedEx & 75.47 & 284.44 & 1.91 & USA \\
\hline 3 & Maersk & 57.65 & $2,254.00$ & -0.89 & Denmark \\
\hline 4 & Hapag-Lloyd & 29.36 & 167.06 & 0.72 & Germany \\
\hline 5 & $\begin{array}{l}\text { Old Dominion } \\
\text { Fright }\end{array}$ & 28.64 & 244.98 & 0.65 & USA \\
\hline 6 & Expeditors & 18.30 & 108.49 & 0.82 & USA \\
\hline 7 & C.H. Robinson & 12.62 & 96.51 & 0.25 & USA \\
\hline 8 & Brambles & 11.99 & 8.22 & 0.95 & Australia \\
\hline 9 & $\begin{array}{l}\text { Orient Overseas } \\
\text { Line }\end{array}$ & 11.18 & 17.56 & -2.98 & Hong Kong \\
\hline 10 & Knight-Swift & 8.19 & 49.47 & -0.44 & USA \\
\hline
\end{tabular}

Source: https://companiesmarketcap.com/transportation/largest-transportation-companies-by-marketcap/ (date of access: 10.04.2021)

Market capitalisation is a measure of market value equal to the current stock price times the number of shares outstanding. Most financial websites will list companies in order of market capitalisation which will also help you choose firms that are similar in size. This is useful, because none wants to compare C.H. Robinson either with a company that is many times larger or smaller.

\section{Conclusion}

It does not seem likely the transportation firms would have that much in common. Note that C.H. Robinson is a pretty big firm but by no means the biggest. There are several firms on the list that are about the same size as C.H. Robinson and also seem to be in about the same line of business. For example, Old Dominion Fright, Expeditors, and Knight-Swift - all deliver transportation services like C.H. Robinson does. We will compare C.H. Robinson to these companies. For ROE, we see that among the firms that are C.H. Robinson's peers there is certainly some healthy ROEs. But C.H. Robinson by far has a much higher ROE than these firms. Based on some experience looking at companies, C.H. Robinson's leverage ratio seems pretty high. It means C.H. Robinson uses so much debt. It is explained by the fact that the firm has been able to support that debt so far due to fiscal stimulus during the coronacrisis. The next step would be going on to doing more research to measure how C.H. 
Robinson is actually currently valued in the market. It could be that C.H. Robinson already has a price that reflects its relatively high ROE. It is worth to learn a lot more about the products that C.H. Robinson and the subsidiaries intend to roll out in the coming months and years. In other words, it is a good start on finding an interesting company, but nowhere near the point where everyone is confident enough in its future success to put money on the line.

Hopefully, this article helps investors feel more comfortable around the company's financial statements. We have learned the basic financial ratios that help us judge the performance of different companies and seen that the way to use ratios is to compare one firm to a group of its peers. Though there is no one single ratio that identifies good companies, $\mathrm{ROE}$ is a good starting point for noticing strong performers. Once you find the company that interests you, look over major ratios to really get a feel for its financial performance, and do not forget to look into the stories behind the numbers like why C.H. Robinson uses so much leverage, and what kinds of new products it will bring to market in the coming years. These stories are really where you will discover the information that will convince you to invest or not to invest.

\section{References}

1. N. Alemany, V. Arago, E. Salvador, International Review of Economics \& Finance, 68(7), 269 (2020)

2. J. S. Cao, J. H. Wang, Soft Computing, 24(11), 7851 (2020)

3. T. J. Cheng, Symmetry, 11(12), 1474 (2019)

4. X. Dong, R. Ma, H. Li, International Review of Financial Analysis, 64(7), 13 (2019)

5. Y. Fu, Z. Su, B. Xu, Y. Zhou, J. of Advances in Computer Intelligent Information, 24(3), 265 (2020)

6. P. Gao, R. Zhang, X. Yang, Mathematical Computer Applications, 25, 53 (2020)

7. Y. G. Hou, S. Li, International Review of Economics \& Finance, 66(3), 166 (2020)

8. J. Q. Hu, T. X. Wang, W. W. Hu, J. Tong, Journal of Futures Markets, 40(7), 1176 (2020)

9. T. Jain, S. Sehgal, R. Agrawal, Vision-The Journal of Business Perspective, 24(3), 356 (2020)

10. Z. Janková, P. Dostal, Trends Economics and Management, 35(1), 45 (2020)

11. K. Khan, H. W. Zhao, H. Zhang, H. L. Yang, M. Haroon, A. Jahanger, Journal of Asian Finance Economics and Business, 7(7), 463 (2020)

12. A. A. Salisu, L. O. Akanni, Emerging Markets Finance and Trade, 56(10), 2310 (2020)

13. P. Sun, T. Weng, H. Yang, Journal of University of Shanghai for Science and Technology, 41(1), 71 (2019) 